\title{
KRITICKÉ ČÍTANIE LITERÁRNEJ TVORBY VÍŤAZOSLAVA HRONCA Z ASPEKTU JEJ INTERTEXTUÁLNEHO CHARAKTERU
}

V príspevku som analyzoval monografiu Maríny Šimákovej Spevákovej, v ktorej táto literárna kritička dôkladne interpretovala celkové literárne dielo najvýznamnejšieho súčasného slovenského vojvodinského spisovatel'a Vít'azoslava Hronca v kontexte jeho intertextuálneho rázu. Pritom som sa zvlášt' zameral na problematiku samotnej intertextuality, predovšetkým na jej implicitný, respektíve explicitný charakter, najviac však na tzv. teóriu citátovosti, ktorú Šimáková Speváková vo svojom výskume dôsledne aplikovala. Súbežne s touto teoreticko-metodologickou problematikou analyzoval som i kritičkinu dôkladnú interpretáciu básnického, prozaického a autoreferenčného diela Vít’azoslava Hronca realizovanú v širšom kontexte premien európskej literatúry, prostredníctvom ktorej Šimáková Spevákova presvedčivo zdokumentovala svoju základnú výskumnú tézu, podl'a ktorej je intertextualita u tohto spisovatel'a základným významotvorným činitel’om, ontologickým princípom a estetickou normou.

Klúčové slová: intertextualita, teória citátovosti, Vít’azoslav Hronec, interpretácia, premeny, európska literatúra, sémantika, estetická norma.

V monografii Podoby intertextuality v tvorbe Vitazoslava Hronca (Šimáková Speváková, 2015), napísanej na podklade obhájenej dizertácie, Marína Šimáková Speváková, docentka na Oddelení slovakistiky Filozofickej fakulty v Novom Sade, analyzovala nielen intertextuálny charakter celkovej literárnej tvorby najvýznamnejšieho slovenského vojvodinského literáta - básnika, prozaika, literárneho kritika, bibliografa, knižného editora a časopiseckého redaktora, Vít'azoslava Hronca, ale zároveň dôkladne (re)konštruovala proces premien jeho literárnej poetiky a životnej filozofie. Je to iste doteraz najsystematickejšie a najúplnejšie kritické čítanie Hroncovho ,nepriepustného diamantu”, ${ }^{2}$ v ktorom sa

\footnotetext{
*svetlika@ptt.rs

1 Metaforou vypožičanou od Charlesa Normana Marína Šimáková Speváková obrazne definovala nielen literárne dielo Vít’azoslava Hronca, ale zároveň i svoj vzt’ah k nemu:
} 
tejto literárnej kritičke podarilo prostredníctvom minucióznej, prenikavej a neraz invenčnej interpretácie básnického a prozaického diela tohto spisovatel'a preniknút' k tým najodl'ahlejším, zatial' ešte stále dostatočne nepreskúmaným priestorom jeho komplexnej, niekedy sa môže zdat' i hermetickej až ezoterickej štruktúry. Napriek dôkladnému rozboru však Šimáková Speváková Hroncovo literárne dielo neprečítala „do konca” a nepoložila bodku za jeho d’alšími kritickými čítaniami čo iste ani nebolo jej ciel'om, o čom svedčí aj autorkino konštatovanie na začiatku monografie: „Je zrejmé, že sme všetky pôvodné (proto)texty a medzitextové ret'azce vyčerpat' nemohli a ani nebolo naším ciel'om nájst' všetky invarianty a varianty intertextuálnych vzt’ahov." (Šimáková Speváková, 2015: 2). Inšpirovaná a očividne i nadšená Hroncovou literárnou tvorbou a využívajúc pritom vlastnú bohatú sčítanost' a primeranú teoreticko-metodologickú „podkutost” („Harpáňova škola”) Šimáková Speváková napísala knihu, ktorú nevnímam len ako „metatextový” dodatok k interpretovanému literárnemu dielu, ale považujem ju za originálny a zaujímavý text, ktorý sa svojou premyslenou a komplexnou štruktúrou v mnohom vyrovná svojmu „prototextovému” inšpiračnému zdroju. Práve preto, okrem prvoradého interpretačného, objasňujúco-hodnotiaceho významu je nemenej dôležitá i ,pragmaticko-propagačná” funkcia tejto monografie, ktorá má za ciel’ prilákat' a podnietit' $\mathrm{k}$ číaniu Hroncovej literárnej tvorby čitatel'ov a literárnych kritikov, predovšetkým však ozajstných literárnych labužníkov, ktorým je toto exkluzívne, významovo bohato navrstvené literárne dielo primárne určené. ${ }^{2}$

Analyzovat' intertextualitu v diele výnimočne erudovaného spisovatel'a, akým je bezpochyby Vít’azoslav Hronec, ${ }^{3}$ vyžadovalo nielen značnú literárnokritickú odvahu, ale i metodologickú pripravenost' a najmä prehl'ad v premenách európskej literatúry, lebo pri takomto výskume sa literárny kritik, v tomto prípade Marína Šimáková Speváková, nepohybuje, obrazne povedané, len v bohatej Hroncovej knižnici, ale tiež v knižniciach početných autorov (James

„Predsa však, zostáva dojem, že Hroncovo dielo, povedané slovami z knihy Charlesa Normana (2011), nad’alej stojí ako nepriepustný diamant.” (Šimáková Speváková, 2015: 1). 2 „Ak náš prístup vyvolá nový čitatel'ský záujem o Hroncove texty, bude to len ukazovatel'om životaschopnosti jeho diela.” (Šimáková Speváková, 2015: 2).

3 Podl'a vlastných slov Vít’azoslav Hronec pri zostavovaní niekol'kých antológií či chrestomatií slovenskej poézie prečítal prakticky celú slovenskú básnickú produkciu. Aj ked' sa o tom explicitne nezmienil, zrejmá je i jeho dôkladná znalost' dejín slovenskej prózy. Na druhej strane vidno, najmä z jeho denníkovej tvorby, že dôverne pozná i srbskú literárnu tradíciu, respektíve juhoslovanské literatúry, a že sústavne čítal (v prekladoch do slovenčiny, srbčiny a češtiny) i najvýznamnejšie diela zo svetovej literatúry. 
Joyce, Thomas Stearns Eliot, Rainer Maria Rilke, Ezra Pound, Raymond Carver, Saint-John Perse, Thomas Pynchon, Ján Stacho, Ján Ondruš, Branko Miljković, Borislav Radović, Miodrag Pavlović, Jovan Hristić a i.), ktorých diela a nepriamo aj ich celoživotnú lektúru tento slovenský vojvodinský spisovatel' integroval do svojej literárnej tvorby. Z tohto dôvodu si skúmanie intertextuality v Hroncovom literárnom diele vyžadovalo predovšetkým zosúladenie „,vlnovej dížky” či spoločného literárno-kultúrneho kódu spisovatel’a a kritického čitatel'a, ${ }^{4}$ t. j. Maríny Šimákovej Spevákovej, čo zároveň predpokladalo nielen primeranú „remeselnícku” kompetenciu a zručnost' tejto kritičky, ale zároveň i jej dobrú vôlu a ochotu ${ }^{5}$ trpezlivo a pozorne „lúštit” svojrázny intertextuálny „rébus”, aký Vít'azoslav Hronec svojou literárnou tvorbou utvoril, respektíve aký ešte stále tvorí.

V analýze intertextuality Hroncovho literárneho diela, predovšetkým prozaického, básnického a autoreferenčného, sa Marína Šimáková Speváková primárne sústredila na samotný text, na jeho ,verné” kritické čítanie, čo z perspektívy jej literárnokritickej metódy znamená odhal'ovanie autorom cielavedome konotovaných významov. Pritom aj samotná vol'ba exaktne overitel'nej explikovanej intertextuality, ako základného zorného uhla $\mathrm{v}$ tomto výskume, signalizuje kritičkinu štrukturalisticko-semiotickú metodologickú orientáciu, ktorá je iste vhodnejšia na „vedeckú” analýzu literárneho textu ako zovšeobecňujúco-abstraktné, neraz i ,špekulatívne” postštrukturalistickodekonštruktívne kritické čítania literatúry, ktoré do výskumu tohto druhu vo väčšej miere zahŕňajú aj „vrtkavú” všeobecnú, respektíve implikovanú intertextualitu. ${ }^{6}$ Svoje základné metodologické východisko Šimáková Speváková vysvetlila $\mathrm{v}$ úvodnej stati monografie, v ktorej zdôvodnila vlastné uprednostnenie teórie

4 „Iba z interakcie textov diela a textov čitatel'a môže vzniknút' jedno z mnohých čítaní postmoderného, polyfónneho a otvoreného diela.” (Šimáková Speváková, 2015: 88).

5 O svojráznom komunikačnom „skrate” medzi Hroncovým básnickým textom a čitatel’om možno najviac svedčí spisovatel'ova autointerpretácia básnickej skladby Hranica I, publikovaná časopisecky a potom i knižne pod názvom Nulový stupeň rétoriky (Hronec, 2008). S týmto problémom sa stretla i Šimáková Speváková, takže neprekvapuje jej konštatovanie: „No prax ukázala, že tak užší kontext, technika montáže, ako aj „nulový stupeň rétoriky" vo veršoch Hranice I., neul'ahčili textu komunikáciu s čitatel'om. Avšak Hroncov text si nad'alej bude hl'adat' svojho, trpezlivého a úporného' (Danojlić) čitatel'a, identifikujúceho autorov vzt’ah k jazyku, nie ku skutočnosti." (Šimáková Speváková, 2015: 44)

${ }^{6}$ Podl'a postštrukturalistov je každý text utkaný z iných textov, teda je vlastne vo svojej podstate intertext. 
citátových relácií od chorvátskej literárnej teoretičky Dubravky Tolićovej Oraićovej, ktorá môže naplno reprezentovat' práve „vedecko-deskriptívne” tendencie vo výskume intertextuality zamerané na systematickú analýzu tzv. osobitnej intertextuality (oproti všeobecnej intertextualite), kde je potom i najväčší dôraz práve na interpretácii explikovanej intertextuality, čiže na odhalovaní a analyzovaní spisovatel'ovho ciel'avedomého zapájania cudzích textov, podl'a Šimákovej Spevákovej pravých a utajených citátov, do novovznikajúceho literárneho textu, ktoré je pritom pre recipienta viditel'né či dokázatel'né a zároveň je pochopitel'ná i jeho autorom zacielená funkcia. Aj ked' chorvátska autorka vo svojej teórii používa termín citátovost', ktorý má často užší význam ako intertextualita, lebo sa vzt’ahuje len na označené cudzie texty, Šimáková Speváková vo svojej monografii predsa najviac využíva termín intertextuálnost'. Týmto spôsobom kritička naznačila svoj širší výskumný záujem aj o niektoré aspekty všeobecnej intertexuality, teda o analýzu komplexnejších medzitextových relácí́ realizujúcich sa prostredníctvom implicitnej, ale i „neintencionálnej”, „podvedomej"7 či „neželanej”, intertextuality, svojrázneho palimpsestového presvitania nielen Hroncovej lektúry, ale i akejsi univerzálnej ,pamäte” samotného jazyka, ${ }^{9}$ ktorú nemožno v úplnosti obsiahnut' len prostredníctvom teórie citátovosti.

${ }^{7}$ Tak napríklad postavu Mary z Hroncovej prózy Prach Šimáková Speváková intertextuálne uvádza do súvislostí s Máriou z Eliotovej Pustatiny, no pritom konštatuje: „V tomto zmysle vidno podobnosti medzi dvoma autormi, ale intertextovost' tu ako v poézii uvedeného obdobia odhalit' nemožno, dá sa uvažovat' o podvedomom alebo náhodnom (zvýraznil A. S.) nadväzovaní." (Šimáková Speváková, 2015: 106).

8 Túto „neželanú”, no implicitne prítomnú intertextualitu možno vidiet' najmä prostredníctvom Hroncovho vzt’ahu k slovenskej vojvodinskej literárnej tradícii, ktorú tento spisovatel' dobre pozná, no voči ktorej mal výrazne kritický postoj. Z tohto dôvodu potom ani neprekvapuje, že je len niekol'ko slovenských vojvodinských spisovatel'ov (Jozef Podradský, Michal Babinka, Pal'o Bohuš a i.), na ktorých diela Hronec vo svojom literárnom texte priamo citátovo naráža, aj ked' je celkom zrejmé, že intertextuálne „stopy” v jeho tvorbe zanechali aj mnohí d’alší slovenskí vojvodinskí autori, ktorých texty „presvitajú" z hlbších rovín Hroncovho literárneho textu. Napokon, aj sám Hronec na jednom mieste v denníku píše: „My vychádzame z Labátha, na jeho poéziu nadväzujeme aj ked' o sebe už môžem tvrdit', že som sa z toho definitívne vyzliekol" (Lutrov, 1997: 37).

9 Vidno to najmä pri symboloch odpozorovaných vintertextuálnych reláciách, kde Hroncovo citovanie ide často do (čitatel'sky) neprehl'adnej hĺbky: „,...) prostredníctvom dialógu s l'udovou rozprávkou, cez stachovský symbol soli, môžeme sledovat', ako Hroncova poézia nadväzuje na tradíciu celoslovenskej literatúry.” (Šimáková Speváková, 
Vychádzajúc teda zo základných postulátov teórie citátovosti Dubravky Tolićovej Oraićovej a aplikujúc pritom dôsledne vo svojom výskume najmä jej dôkladne rozpracovanú terminologickú sústavu a triedenie citátov, Šimákovej Spevákovej sa podarilo identifikovat' a klasifikovat' vel'ké množstvo citátov a citačných relácií v Hroncovom literárnom diele, ktoré podl’a tejto kritičky môžu byt' iluminatívne, podiel'ajúce sa na „utváraní nových významov na pozadí starých” (Šimáková Speváková, 2015: 2) a autoreferenčné, ktoré bud' ilustrujú postmodernistické „prúdenia textov autorovým vedomím” (Šimáková Speváková, 2015: 2), alebo formujú spisovatel'ov „,negatívny vzt'ah k prototextu” (Šimáková Speváková, 2015: 2). Kritička sa však nezastavuje len pri takomto v podstate taxatívno-deskriptívnom výskume, ale získané exaktne overitel'né poznatky využíva na podporenie a presvedčivé zdôvodnenie svojej základnej pracovnej (hypo)tézy, podla ktorej „,intertextualita v tvorbe Vít’azoslava Hronca tvorí jadro poetiky, sémantiky a kl'úč k uchopeniu rozmerov jeho literárneho sveta" (Šimáková Speváková, 2015: 182), pričom intertextualita tu nie je len „literárny postup, sémantický a ontologický princíp tvorby, ale i estetická norma, miera umeleckej pôsobivosti literárneho diela." (Šimáková Speváková, 2015: 2).

Šimáková Speváková skúma intertextuálny charakter Hroncovej literárnej tvorby predovšetkým z perspektívy spisovatel'ovej eliotovsky pochopenej kritickoafirmatívnej nadväznosti na literárnu tradíciu, ${ }^{10}$ konkrétne na diela niektorých literárnych klasikov, ${ }^{11}$ ktorých tvorba poznačila staršie obdobia svetovej literatúry (Epos o Gilgamešovi, Homérove eposy, Danteho Božská komédia a i.), ale najmä na literárne diela najvýznamnejších modernistických spisovatel'ov z prvej polovice 20. storočia: Thomasa Stearnsa Eliota, Ezru Pounda, Saint-Johna Persea, Rainera Maria Rilkeho, Jamesa Joycea a d’alších. Už pri letmom čítaní Hroncovej poézie a prózy viditel'ný je silný modernisticko-avantgardistický „tlak” na jeho tvorbu, ktorý spôsobil spisovatel'ovu priam frustrujúcu potrebu permanentnej tvorivej inovatívnosti či originality. Vidno to už aj $v$ Hroncovej modernisticky

2015: 28). Na inom mieste kritička intertetxualitu definuje aj ako ,palimsest kultúrnej pamäti” (Šimáková Speváková, 2015: 90).

10 „Ciel'om analýz je ukázat', že intertextuálne vzt’ahy zohl'adňujú i Hroncov dvojaký vzt'ah k literárnej tradícii. Vykresl'ujú profil autora, ktorý svoje originálne dielo utvára na pozadí kriticko-analytického vstrebávania literárnej tradície.” (Šimáková Speváková, 2015: 2).

11 Šimáková Speváková označuje literárnu tvorbu klasikov i termínom „,kánonické texty” i týmto spôsobom potvrdzuje svoju scientistickú „,vieru” v existenciu nespochybnitel'ných hodnôt, ktoré nepodliehajú subjektívnej či kontextovej relativizácii. 
skoncipovanej básnickej a prozaickej tvorbe $\mathrm{v} 70$. a začiatkom 80. rokov, ale ešte viac sa to prejavuje v jeho (neo)avantgardistických umeleckých experimentoch, predovšetkým v performancii, ktorú pomenoval Umenie vody (Hronec, 1989). Takáto typická modernistická tendencia v Hroncovej tvorbe však bola koncom 80 . rokov 20. storočia utlmená a vo vel'kej miere i spochybnená, čo Šimáková Speváková presvedčivo zdôvodňuje dôkladnou interpretáciou spisovatel'ovho básnického a prozaického diela, usúvzt’ažňujúc výsledky tohto výskumu jednak so súdobými modernisticko-postmodernistickými literárnymi premenami, konkrétne s pribúdaním poznávacej a tvorivej pochybovačnosti spôsobenej vtedy už vel'mi hlasnou postmodernistickou tézou o „vyčerpanosti” jazyka, o jeho ,prirodzenom” intertextuálnom charaktere a o limitoch jeho prezentačných možností, teda aj o limitovaní umelcovej kreativity a originality. Podl’a Šimákovej Spevákovej však nemenej dôležitú funkciu v tomto Hroncovom pokuse o, obrazne povedané, únik zo zajatia neskorého modernizmu a $\mathrm{z}$ druhej vlny avantgardizmu a zakotvenie v postmoderne zohrali i určité autonómne procesy vo vnútri spisovatel'ovej tvorby z tohto obdobia, najmä vzájomné prelínanie a ovplyvňovanie jeho básnickej a prozaickej tvorby, respektíve poetiky: „Hronec sa pri písaní básní väčšinou nesprával ako lyrik, ale vychádzal z udalostí a príbehov, tak imaginárnych, ako aj skutočných, ktoré sprostredkúval básnickým podobenstvom. Na druhej strane, ani v próze nie je „,̌istým” epikom, lebo príbehy zapisoval ako zámienku na úvahy a reflexie svojich postáv a rozprávačov.” (Šimáková Speváková, 2015: 108-109).

Všetky tieto modernisticko-postmoderné posuny a premeny v literárnej tvorbe Vít'azoslava Hronca, ako aj vzájomné dopĺn̆anie, prepájanie a nadväzovanie jednotlivých literárnych textov, žánrov a tvorivých období vo svojej monografii Šimáková Speváková zdokumentovala predovšetkým prostredníctvom zatial' iste najdôkladnejšej interpretácie prakticky všetkých relevantných básní, básnických skladieb, próz, ako i značnej časti spisovatel’ových sebareferenčných ,apendixov”. Pritom najväčší predel v jeho tvorbe, ktorý sa udial v 80. rokoch 20. storočia, teda Hroncov ,prechod” z moderny, respektíve neoavantgardy, do postmoderny kritička vel'mi dôvtipne definovala ako premenu, prostredníctvom ktorej sa tento spisovatel' zo „slovenského Eliota”, vyzdvihujúceho korelatívny vzt’ah medzi tradíciou a novovzniknutým literárnym dielom, stál „slovenský Bloom”, ${ }^{12}$ ktorý vzt'ah

${ }^{12}$ Kritička tu na Hronca aplikuje teóriu amerického dekoštrukcionistu Harolda Blooma, ktorý vzt’ah spisovatel'a k tradícii vysvetl'oval „psychoanalyticky” ambivalentne, ako obdiv voči otcom, ale zároveň i negáciu, potrebu prekonat to „staré” a utvorit' niečo nové, originálne: „Podl’a Blooma môže kánon vytvorit’ iba to literárne dielo, ktoré prekoná, 
k tradícii vnímal ako „úzkost’ z vplyvu”, spôsobujúcu spisovatel’ovu permanentnú potrebu kritickej revalorizácie literárnej tradície. ${ }^{13}$ Tieto závažné premeny v Hroncovej poetike Šimáková Speváková vel’mi pozorne a nuansovane analyzuje a odhal'uje hlavne $\mathrm{v}$ jeho beletristickej tvorbe, no najexplicitnejším dokladom takejto metamorfózy, teda potreby „zúčtovat” s literárnou tradíciou, predovšetkým slovenskou, sú iste Hroncove početné antológie, chrestomatie a (kritické) výbery z tvorby jednotlivých slovenských (vojvodinských) spisovatel'ov, ale tiež literárnokritické a sebareflexívne texty a denníky, v ktorých sa tento spisovatel' zanietene a nekompromisne vyrovnáva najmä so slovenskou „romantizujúcou” literárnou tradíciou, oproti ktorej nielen pri výbere a hodnotení básní a básnikov, ale aj vo vlastnej básnickej tvorbe uprednostňuje tzv. „poéziu klasickej inšpirácie".

(Re)konštrukciou najdôležitejších Hroncových poetologických premien odpozorovaných a zdokumentovaných predovšetkým v kontexte intertextuality sa Marína Šimáková Speváková usilovala potvrdit’ svoju výskumnú (hypo)tézu, podl’a ktorej tento slovenský vojvodinský spisovatel' do svojho postmoderného prejavu tvorivo integroval modernistickú poetiku, čo podl'a tejto kritičky znamená, že je Hronec „dedičom modernizmu, ale zároveň predstavitel’om novej postmodernistickej epochy, ako dvoch strán tej istej mince." (Šimáková Speváková, 2015: 116). Dokladom toho, že v tvorbe tohto spisovatel'a je „modernizmus obsiahnutý v postmodernizme" (Šimáková Speváková, 2015: 142), je aj jeho zjavná potreba permanentného prehodnocovania nielen cudzej, ale tiež vlastnej tvorby, a to neraz i tak, že niektoré svoje modernistické texty tento spisovatel' dodatočne či retroaktívne korigoval, „dotváral” a takto ich integroval do kontextu svojej neskoršej (postmodernej) poetiky. Hronec teda podla Šimákovej Spevákovej „pri utváraní jednotlivých próz nebol v zajatí vlastného konceptu, ale jeho prózy vznikali ako samostatné významovo-naratívne celky, ktoré mnohé súvislosti a ucelenú podobu nadobudli dodatočne.” (Šimáková Speváková, 2015: 118), čo

\footnotetext{
úzkost' z vplyvu’ ostatných kanónov.” (Šimáková Speváková, 2015: 91). Takýto vzt'ah sa u Hronca azda najexplicitnejšie prejavil v básňach Otcovia I. a II. a Synovia I. a II., intertextuálne nadväzujúcich na Homéra, J. Joycea, M. Babinku a P. Bohuša.

${ }^{13}$ „Hronec si teda od samotných začiatkov uvedomoval, že na originálny básnický výraz sa potrebuje vyrovnat' s vlastnou skúsenost'ou a akríbiou svojich predchodcov." (Šimáková Speváková, 2015: 10).
} 
vidno i v poézii, predovšetkým vo vel'kom počte variantov jednotlivých básní. ${ }^{14}$ Názorne sa to prejavilo najmä na príklade Hroncovej básnickej knihy Almagest (Hronec, 1999) z jeho súborného diela, ktorá funguje ako osobitná postmoderná zbierka, aj napriek tomu, že je zostavená i z jeho starších, modernistických básní. Takéto autointerpretačné retroaktívne zásahy, ktoré sú u Hronca skôr pravidlom ako výnimkou, a ktoré Marína Šimáková Speváková vel'mi citlivo, nuansovane a pozorne interpretuje, majú silné modernistické zafarbenie, lebo odzrkadl'ujú spisovatel'ovu „posadnutost”' celkom, ktorý autor utvára, i ked' ho (navonok) rozrušuje. ${ }^{15}$ Práve pre takúto typickú modernistickú „totalizujúcu” tendenciu by som Hroncovu neskoršiu tvorbu, najmä tú v 90. rokoch 20. storočia, predsa len nedefinoval ako „modernizmus obsiahnutý postmodernizmom”, ako to urobila Šimáková Speváková, ale charakterizoval skôr ako postmodernizmus rámcovaný či „pretlmočený” (neskorým) modernizmom.

To, čo je pri čítaní Hroncovho diela zjavné, a čo i Šimáková Speváková vo svojej interpretácii naznačuje, je zdanie, že tento spisovatel' aj napriek „úzkosti z vplyvu" predsa celkom nepodl'ahol typickej postmodernistickej skepse prameniacej v pocite ,vyčerpanosti” literatúry či jazyka. Vidno to predovšetkým na vel'mi premyslenej koncepcii Hroncovej celkovej (literárnej) činnosti, ktorá na rozdiel od postmodernej skepsy jednoznačne evokuje spisovatel'ovu modernistickú vieru v zmysel a význam literatúry a následne i vlastnej (literárnej) tvorby. Všeobecne sa tento jeho „optimizmus” manifestuje v premyslenom, ciel’avedomom a viac-menej i pravidelnom striedaní uprednostnených literárnych druhov či žánrov (poézia, próza, esej atd'.) a poetík (modernizmus, postmoderna, hyperrealizmus a i.) v jednotlivých tvorivých obdobiach. Pritom i usúvzt'ažnenost' a prepojenost' básnickej a prozaickej tvorby, ${ }^{16}$ ktoré Šimáková Speváková zdokumentovala

\footnotetext{
${ }^{14}$ Napríklad premena názvu básnickej skladby Kolesá, hviezdy moje na Hviezdy, pobrežie, o ktorej sa zmieňuje i Šimáková Speváková, nenaznačujúc však ideologické pozadie tejto zmeny (kolesá - dialektika).

${ }^{15}$ Jeho základný tvorivý postulát v druhom tvorivom období - budovat' svet tak, že ho budeme neustále rozdrobovat', dekonštruovat’: „(...) chcem zistit' / či sa epický priestor dá vybudovat' tým / že ho neprestajne budem rozrušovat”' (Hronec, 1999: 136) ) má zjavnú ambivalentnú príchut'. $\mathrm{Na}$ jednej strane si spisovatel' uvedomuje chaotickost' a fragmentárnost' skutočnosti a evokuje to prostredníctvom jednotlivých literárnych textov, na druhej strane sa predsa len nezrieka ideálu celku a cielavedome permanentne „zaokrúhl'uje” svoje celoživotné dielo.

16 „Hroncova prozaická tvorba teda vznikla na základoch básnickej tvorby prvých troch zbierok." (Šimáková Speváková, 2015: 60).
} 
prostredníctvom vyčerpávajúcich interpretácií literárnych textov $\mathrm{v}$ kontexte poetologických premien tohto spisovatel'a, naplno svedčia o totalizujúcich či harmonizujúcich tendenciách v Hroncovej tvorbe. ${ }^{17}$ Vidno to však i na tematickom pláne literárneho diela Vít’azoslava Hronca, v ktorom tento ideál celku spisovatel' naznačuje prostredníctvom častých motívov cyklu, cyklickej návratnosti, kruhu, reinkarnácie, či nesmrtel’nosti. Napokon, aj jedna z posledných „testamentárnych” Hroncových básní, Druhý príchod (Hronec, 1999: 153), ak ju nečítame ironicky, ${ }^{18}$ vyznieva „harmonizujúco”, lebo u čitatel’a evokuje význam cyklickosti, návratu, obnovy i nezničitel'nosti (poézie). V takom tóne svoje kritické čítanie uzaviera aj monografistka: „Celistvost' Hroncovho literárneho diela sa však zrkadlí iba $\mathrm{v}$ rekonštrukcii fragmentov, no aj uvedené zrkadlenie $\mathrm{v}$ konečnom dôsledku poukazuje na potenciálne vít'azstvo poriadku nad ničivými silami chaosu." (Šimáková Speváková, 2015: 180).

Aj Šimáková Speváková, ktorá si plne uvedomuje Hroncovo zanietené celoživotné usúvzt’ažňovanie „všetkého so všetkým”, analyzuje dielo tohto spisovatel'a z perspektívy celku, t. j. interpretovaný text neustále posúva do širšieho kontextu Hroncovej tvorby a zároveň prostredníctvom jeho intertextuálneho charakteru i do širších komparatívnych súvislostí so slovenskou, srbskou a svetovou literatúrou, kde sa podl'a tejto kritičky potom naplno prejavuje význam a hodnota literárnej tvorby tohto spisovatel'a. Práve tento dojem premyslenosti a ucelenosti literárneho diela Vít'azoslava Hronca zrejme natol'ko učaril aj autorke monografie, že ho i ona sama niekedy dodatočne, svojimi interpretáciami a hodnoteniami „harmonizuje”, pričom empaticky, no zároveň presvedčivo scel'uje niektoré „štrbiny”, ktoré sa spisovatel'ovi nepodarilo celkom „zahladit”. Nie je to však prejav nekritickosti či zbožnosti voči tomuto spisovatel'ovi; skôr je to výraz vhlbovania sa, teda pozorného a dôkladného výskumu literárneho textu a zároveň následok ,zlad’ovania kroku” či zosúladenia kritického prejavu s analyzovaným textom, čo je iste nevyhnutnou podmienkou každého úspešného kritického čítania literatúry.

17 „Hroncova poézia a próza tak tvoria poetologický a sémantický kruh.” (Šimáková Speváková, 2015: 65).

${ }^{18}$ Pri kritickom čítaní Hroncovho diela by som bol obozretný, ked' ide o iróniu ako autorský postoj, ktorá je podl'a mňa jednoznačne využívaná len v jeho druhom básnickom tvorivom období. V próze je irónia menej viditel’ná - a neprečítaná či „nepochopená” irónia nie je iróniou. 
Paralelne s dôkladnou interpretáciou básnických zbierok a prozaických kníh Vítazoslava Hronca a zdôvodňovania ich vzájomnej podmienenosti a prepojenosti, Šimáková Speváková analyzovala aj „paraliterárnu” čast' tvorby tohto spisovatel'a, ktorá rozsahom možno i prevyšuje jeho primárne beletristické dielo. Tieto rozličné poznámky, dodatky, doplnky, chronológie, denníky a (auto)interpretácie Šimáková Speváková vníma predovšetkým ,ako citáty, ako súčast' básnickej i prozaickej tvorby a intertextuálnych procesov Hroncových básní a próz" (Šimáková Speváková, 2015: 1), takže ich i interpretuje ako integrálnu čast' celkového literárneho diela tohto autora. Ale napriek tomu, že ich vníma aj ako svojráznu spisovatel’ovu „pomoc” pre tých „nechápavých”, akými sú „literárni kritici, ktorí nepochopia jeho dielo, alebo širšia čitatel'ská verejnost', ktorá by mohla básnikovi ubližit jeho nepochopením a odmietaním." (Šimáková Speváková, 2015: 53), sa monografistka vo svojom výskume predsa už menej zameriava na ich, podl'a mňa tiež dôležitý, (auto)interpretačný aspekt a funkciu, respektíve na ich hybridný beletristicko-literárnokritický, v podstate typický postmoderný charakter. Zjavne tu prichádza znovu k slovu spisovatel'ova, ale zároveň bádatel'kina viera v prezentačné možnosti literárneho textu či jazyka, ktoré recipientovi sprostredkujú autentický, autorom konotovaný význam, takže v takomto postoji k tým „nechápavým” čitatel'om a kritikom sa nepriamo prejavuje i zjavná kritika postštrukturalistickej subjektivizácie a relativizácie kritického čítania literatúry. ${ }^{19}$ Vnímam to však opät' ako modernistické rezíduum, ktoré je tu len zabalené v postmodernej forme, lebo o intertextualite, ako napokon aj o každom inom aspekte literárneho textu môžeme hovorit' iba z pozície recipienta čiže čitatel'a/kritika, takže bez ohl'adu na autorovo želanie a „smernicové” konštruovanie textu a bez ohl'adu na jeho viac-menej transparentné konotovanie, text a v tomto prípade i jeho intertextuálny charakter odhal'uje vždy len čitatel'. Inými slovami povedané: „neprečítaná” či „neodhalená” intertextualita nie je intertextualita. Práve z tohto dôvodu kritický čitatel' môže prihliadat' na tieto autorove (seba)interpretačne smernice, no musí ich vždy vnímat' s rezervou, teda nie ako nejaký fakt, ktorý on musí v texte odhalit', ale skôr ako autorovo želanie a niekedy i jeho, či už podvedomú, alebo i ciel'avedomú mystifikáciu.

19 „Hronec akoby neočakával, že jeho čitatel' odhalí udalosti v podtextoch, lebo si je vedomý, že vzt’ah voči skutočnosti neurčuje priama tematizácia udalostí, ale predovšetkým vzt'ah k jazyku. Hronec čitatel'ovi k odhaleniu skutočnostného podkladu necháva pootvorené dvere, aby si uvedomil, že verše sú podložené konkrétnymi príhodami." (Šimáková Speváková, 2015: 39). 
Domnievam sa, že Marína Šimáková Speváková svojím kritickým čítaním Hroncových literárnych textov aj napriek vel'kému vynaloženému úsiliu a zanieteniu predsa len $\mathrm{v}$ úplnosti nezistila, čo chcel tento spisovatel' svojou komplexnou a výrazne premyslenou tvorbou dosiahnut', povedat', vytvorit', čo ani nebolo, ako som naznačil, jej ciel'om. Zistila však a pre budúcich čitatel'ov Hroncovho literárneho diela to potom i vel'mi dôkladne a presvedčivo v monografii zdokumentovala, vysvetlila a zhodnotila, čo Hroncova tvorba hovorí jej, čo znamená pre ňu, aké otázky, prípadne i odpovede, respektíve významy a hodnoty jej sprostredkuje, evokuje. Úprimne však verím, že medzi pôvodným Hroncovým tvorivým predsavzatím, jeho textovou (jazykovou) realizáciou a následne jeho (kritickým) (pre)čítaním Marínou Šimákovou Spevákovou nie je zásadný rozdiel.

Adam Svetlík

\section{KRITIČKO ČITANJE KNJIŽEVNOG STVARALAŠTVA VIĆAZOSLAVA HRONJECA SA ASPEKTA NJEGOVOG INTERTEKSTUALNOG KARATERA}

\section{Sažetak}

U radu analiziram monografiu Marine Šimakove Spevakove Intertekstualnost u stvaralaštvu Vićazoslava Hronjeca (Podoby intertextuality v tvorbe Vitazoslava Hronca), u kojoj je ova književna kritičarka sistematski interpretirala književno delo Vićazoslava Hronjeca sa aspekta njegovog intertekstualnog karaktera. Poseban akcenat u ovoj analizi je na teorijskometodološkoj problematici same intertekstualnosti, dakle problemima opšte i pojedinačne, odnosno eksplicitne i implicitne intertekstualnosti, ali pre svega na tzv. teoriji citatnosti, koju je u svom radu aplikovala autorka monografije. Paralelno sa ovom teorijskom problematikom istražujem i način na koji je Šimakova Spevakova, temeljito i nijansirano, analizirala stvaralačke tendencije u Hronjecovom književnom delu sagledane u kontekstu promena evropske književnosti, naročito njenog prelaska iz moderne u postmodernu u drugoj polovini 20. veka. Analiza istraživačkog rada Šimakove Spevakove je pokazala, da je ova književna kritičarka, kroz iscrpnu analizu Hronjecovog pesničkog, proznog i autorefleksivnog dela, uspela u velikoj meri da dokaže svoju početnu tezu prema kojoj je intertekstualnost osnovna stvaralačka metoda, sematički i ontološki princip, ali i estetička norma književnog teksta ovog pisca.

Ključne reči: monografija, Marina Šimakova Spevakova, Vićazoslav Hronjec, intertekstualnost, teorija citatnosti, moderna, postmoderna, semantička, estetička norma. 
Adam Svetlík

\section{A CRITICAL READING OF HRONEC'S LITERARY WORK FROM THE PERSPECTIVE OF INTERTEXTUALITY}

\section{Summary}

This article analyzes the monograph Intertextuality in Vitazoslav Hronec's literary work (Podoby intertextuality v tvorbe Vitazoslava Hronca) by Marina Šimáková Spevákova, in which she interpreted Hronec's literary work systematically from the perspective of intertextuality. The emphasis is on the theoretical and methodological problematics of intertextuality itself, i.e. her explicit and implicit nature and the theory of citation, which is effectively applied in Šimáková Speváková's work. Parallel to these theoretical problematics, the article discusses Šimáková Speváková's method for her thorough and nuanced analysis, which is based on Hronec's literary tendencies in the context of a change in European literature, especially through the transition period from modern to postmodern literature in the second half of the twentieth century. Through an analysis of Hronec's poetic, prose and autoreflexive work, Šimáková Speváková manages to prove to a large extent her initial thesis according to which intertextuality is the basic creative method, the semantic and ontological principle, and also the aesthetic norm in Hronec's literary work.

Key words: monograph, Marina Šimáková Spevákova, Vit’azoslav Hronec, intertextuality, theory of citation, modern, postmodern, semantics, aesthetic norm

\section{LITERATÚRA}

Hronec, V. (1989). Manifest umenia vody. Novýz život, 41, 12, 64-66.

Hronec, V. (1999). Almagest. Beograd, Báčsky Petrovec: Zavod za izdavanje udžbenika, Kultúra.

Hronec, V. (2008). Nulový stupeň rétoriky. Stará Pazova: Art centrum Chlieb a hry. Lutrov, V. (1997). Stretnutie s Minotaurom. Báčsky Petrovec: Kultúra Šimáková-Speváková, M. (2015). Podoby intertextuality v tvorbe Vit’azoslava Hronca. Novi Sad: Vojvođanska akademija nauka i umetnosti. 